\title{
DÜBLIN
}

Technological University Dublin

ARROW@TU Dublin

\section{An Effective Method for the Preparation of High Temperature Stable Anatase TiO2 Photocatalysts}

\author{
Rachel Fagan \\ Technological University Dublin, rachel.fagan@mydit.ie \\ Declan McCormack \\ Technological University Dublin, Declan.mccormack@tudublin.ie \\ Suresh Pillai \\ Technological University Dublin, Pillai.suresh@itsligo.ie
}

See next page for additional authors

Follow this and additional works at: https://arrow.tudublin.ie/scschcpsart

Part of the Analytical Chemistry Commons, Materials Chemistry Commons, and the Physical Chemistry Commons

\section{Recommended Citation \\ Fagan, R., Synnott, D. W., McCormack, D. and Pillai, S. (2016) An effective method for the preparation of high temperature stable anatase TiO2 photocatalysts. Applied Surface Science, Vol. 371. 15 May 2016, Pages 447-452. doi:10.1016/j.apsusc.2016.02.235}

This Article is brought to you for free and open access by the School of Chemical and Pharmaceutical Sciences at ARROW@TU Dublin. It has been accepted for inclusion in Articles by an authorized administrator of ARROW@TU

Dublin. For more information, please contact

arrow.admin@tudublin.ie, aisling.coyne@tudublin.ie, gerard.connolly@tudublin.ie.

Funder: Science Foundation Ireland

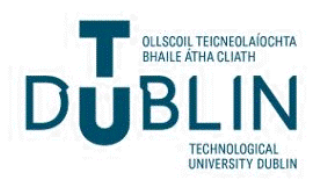




\section{Authors}

Rachel Fagan, Declan McCormack, Suresh Pillai, and Damian Synnott

This article is available at ARROW@TU Dublin: https://arrow.tudublin.ie/scschcpsart/55 


\title{
An Effective Method for the Preparation of High
}

\section{Temperature Stable Anatase $\mathrm{TiO}_{2}$ Photocatalysts}

\author{
Rachel Fagan, ${ }^{\text {a,b }}$ Damian W. Synnott, ${ }^{\mathrm{a}, \mathrm{b}}$ Declan E. McCormack, ${ }^{\mathrm{a}, \mathrm{b}^{*}}$ and Suresh C. Pillai ${ }^{\mathrm{d}, \mathrm{e},{ }^{*}}$ \\ ${ }^{a}$ Centre for Research in Engineering Surface Technology (CREST), FOCAS Institute, Dublin \\ Institute of Technology, Kevin St, Dublin 8, Ireland \\ ${ }^{b}$ School of Chemical and Pharmaceutical Sciences, Dublin Institute of Technology, Kevin St., \\ Dublin 8, Ireland \\ ${ }^{d}$ Nanotechnology Research Group, Department of Environmental Sciences, Institute of \\ Technology Sligo, Ireland \\ ${ }^{e}$ Centre for Precision Engineering, Materials and Manufacturing Research (PEM), Institute of \\ Technology Sligo, Sligo, Ireland
}

\begin{abstract}
An efficient, rapid and straightforward method for the preparation of nitrogen and fluorine (N, F) codoped high temperature stable anatase using a microwave pre-treatment is reported. Using a single source, ammonium fluoride $\left(\mathrm{NH}_{4} \mathrm{~F}\right)$ for both nitrogen and fluorine, effective doping of the precursor titanium isopropoxide (TTIP) was possible. These samples were characterised for their structural and optical properties using X-ray diffraction (XRD), Fourier transform IR (FTIR), Raman spectroscopy and UV-vis spectroscopy. In terms of the anatase to rutile transition enhancement using a novel microwave assisted technique, the sample prepared in a composition
\end{abstract}


of 1:8 $\mathrm{TiO}_{2}: \mathrm{NH}_{4} \mathrm{~F}$ at $1200{ }^{\circ} \mathrm{C}$ was seen to be most effective, having stable anatase present at $57.1 \%$ compared to undoped $\mathrm{TiO}_{2}$ being $100 \%$ rutile from $900{ }^{\circ} \mathrm{C}$. This method involves the production of ammonium oxofluorotitanates $\left(\mathrm{NH}_{4} \mathrm{TiOF}_{3}\right)$ at low temperatures. The inclusion of these intermediates greatly reduces the particle size growth and delays the anatase to rutile transition. The photocatalytic activity of these materials was studied by analysing the degradation of an organic dye, rhodamine $6 \mathrm{G}$ as a model system and the rate constant was calculated by pseudo-first-order kinetics. These results showed that the doped sample $(0.0225$ $\left.\min ^{-1}\right)$ was three times more active than the undoped sample $\left(0.0076 \mathrm{~min}^{-1}\right)$ and over seven times faster than the commercial $\mathrm{TiO}_{2}$ photocatalyst standard Degussa P-25 calcined at $1200{ }^{\circ} \mathrm{C}$ $\left(0.0030 \mathrm{~min}^{-1}\right)$. The formation of intermediate compounds, oxofluorotitanates, was identified as the major reason for a delay in the anatase to rutile transition.

\section{Introduction}

Titanium dioxide $\left(\mathrm{TiO}_{2}\right)$ is an environmental friendly semiconductor photocatalyst used for various purposes including water splitting [1,2], self-cleaning [3-6], sterilisation [7], antifogging [8], lithography [9], degradation of organic compounds [10,11], and metal corrosion prevention $[12,13]$. The advantages of $\mathrm{TiO}_{2}$ are its chemical stability, durability, nontoxicity, low cost, and transparency to visible light. In photocatalysis, there are many factors involved in producing a photocatalytically active material. The phase composition [1], surface composition [14], the affinity of the organic molecules toward the surface [15], surface area [16], and the level of electron-hole recombination [17] are properties reported as having major impacts in the rate of photocatalysis. This can conclude that, it is not one factor alone that will affect the rate of 
reaction; it is a combination of the above at certain conditions that will provide the optimum photocatalyst.

The stability of high temperature anatase has been an area of continuous study over the years [18]. The use of cations (usually metals) for the doping of $\mathrm{TiO}_{2}$ was generally avoided due to their tendency to increase charge carrier recombination centres [19], and the generation of secondary impurity phases which inevitably reduces the photo-activity of titania [20]. It was also suggested that despite the decrease in band gap energy, metals were not always successfully introduced into the $\mathrm{TiO}_{2}$ framework, and that the remaining metals on the outside surface sheltered the photo-reaction sites [21]. To counter these reported issues, a number of papers have been published in recent times on the extension of the anatase to rutile transformation by nonmetal doping of $\mathrm{TiO}_{2}$. Sulfur doping through the use of sulphuric acid allowed the retention of anatase at $100 \%$ at $800{ }^{\circ} \mathrm{C}$ and $20 \%$ at a temperature as high as $900{ }^{\circ} \mathrm{C}$ [22]. Further on to this work, a combination of nitrogen and sulphur doping provided materials of $100 \%$ anatase at 850 ${ }^{\circ} \mathrm{C}$ [23]. Doping with fluorine was also found to be a promising route of obtaining high temperature stable anatase with literature showing that the highest published levels of retained anatase are attained from using sources of fluorine. Padmanabhan et al., [24] used trifluoroacetic acid as the fluorine source, which provided significant stable anatase being retained up to 900 ${ }^{\circ} \mathrm{C}$. Lv et al., obtained F-doped anatase $\mathrm{TiO}_{2}$ nanoparticles prepared via the alcoholysis of $\mathrm{TiCl}_{4}$ showing stability up to $1000{ }^{\circ} \mathrm{C}$ before being transformed into the rutile structure, with $40 \%$ anatase present up to $1150{ }^{\circ} \mathrm{C}$ [25]. Lv et al., also studied the effectiveness of fluorine and through the use of hydrofluoric acid as an additive, surface fluorinated $\mathrm{TiO}_{2}$ nanosheets were successfully prepared with anatase present at $8 \%$ at $1200{ }^{\circ} \mathrm{C}[26]$. The study conducted by $\operatorname{Lv}$ et 
al. [26], showed that the fluorine ions not only provide a thermally stable material but also increased the photocatalytic activity of the resulting materials.

Photocatalysts have proven to be a solution to a number of environmental problems including water decontamination, treatment of waste products and disinfection of hospital surfaces where harmful anti-bacterial resistant bacteria such as MRSA and $C$. diff may form. Self - cleaning building materials such as glass, ceramic and roof tiles can be used in hospital and other health care facilities to provide a clean disinfected environment [19,27]. The advantage of high temperature stable anti-microbial anatase is that the photocatalyst can be applied to products which are processed at high temperatures (e.g. ceramic tiles or toilet fittings). Building materials such as ceramic tiles, roof tiles and glass are produced at high temperatures ranging from $650-$ $1100{ }^{\circ} \mathrm{C}$. If $\mathrm{TiO}_{2}$ were to be applied to these materials during the manufacturing process it would convert to the non-photocatalytically active rutile phase resulting in the need to develop a method of preparing a high temperature stable anatase. By developing a synthesis method whereby the photocatalytic active anatase phase is retained to higher temperatures, self-cleaning building materials can be produced without too much modification to the existing manufacturing techniques [1]. Throughout the study described in this paper, a novel methodology was investigated to obtain a high temperature stable sample with high levels of anatase present. This synthesis route provided a straight forward, easy to reproduce and cost effective method to develop high temperature stable anatase $\mathrm{TiO}_{2}$.

In this paper, the use of microwave irradiation as a pre-treatment step in the preparation of $\mathrm{TiO}_{2}$, with the aim of producing a stable anatase phase at higher temperatures is studied. Research into microwave assisted preparation of nanomaterials has been studied for its effectiveness against 
more conventional methods [28]. Microwave treatment was investigated to measure whether this pre-treatment step produced an enhanced, more active, improved catalytic performance when compared to other methods such as sol-gel processing. Ammonium fluoride $\left(\mathrm{NH}_{4} \mathrm{~F}\right)$ was used as the precursor in this study providing both $\mathrm{N}$ and $\mathrm{F}$ ions, with $\mathrm{NH}_{4} \mathrm{~F}$ showing past success in effectively improving the photocatalytic activity and anatase to rutile transition temperature $[29,30]$. Co-doping with both $\mathrm{N}$ and $\mathrm{F}$ atoms provides a change in the photocatalytic capabilities of the $\mathrm{TiO}_{2}$ at a larger scale than those changes caused by each dopant individually [31,32].

\section{Experimental}

\subsection{Materials}

In this study, titanium tetraisopropoxide (97.0\%), isopropanol $(99.0 \%)$, ammonium fluoride (>98.0\%) were purchased from Aldrich and were used without further purification to prepare the samples. The dye used for the photocatalytic study (rhodamine 6G) was obtained from Eastman and was of analytical reagent grade and used without further purification. Deionised water was used in all experiments.

\subsection{Preparation of nanomaterials}

In a typical experiment to prepare a 1:1 titania: ammonium fluoride sample, $18.72 \mathrm{mls}$ of titanium isopropoxide $\left(\mathrm{Ti}(\mathrm{OPr})_{4}\right)$ was added slowly with stirring to $164.2 \mathrm{mls}$ of isopropanol. To this solution, a mixture of $2.37 \mathrm{~g}$ of ammonium fluoride $\left(\mathrm{NH}_{4} \mathrm{~F}\right)$ in 240 mls of deionised water was added drop wise. The precipitate was stirred for 2 hours at room temperature. The resulting solution was then irradiated in a CEM MARS 5 
microwave system under ambient pressure at 400 watts for 20 minutes. The irradiated precipitate was then filtered and the solid obtained was washed with $100 \mathrm{~mL}$ of deionised water. The resulting solid was placed in an oven at $80{ }^{\circ} \mathrm{C}$ to dry. The dried powder was calcined at $100{ }^{\circ} \mathrm{C}$ intervals ranging from $200-1200{ }^{\circ} \mathrm{C}$ with a ramp rate of $5{ }^{\circ} \mathrm{C} / \mathrm{min}$ and held at these temperatures for a 2 hour period. Samples were prepared with varying ratios of $\mathrm{TiO}_{2}$ to dopants, i.e. $1: 1,1: 2,1: 4$ and $1: 8 \mathrm{TiO}_{2}: \mathrm{NH}_{4} \mathrm{~F}$.

\subsection{Characterisation}

A combination of analytical techniques was used allowing the full characterisation of the $\mathrm{N}, \mathrm{F}-\mathrm{TiO}_{2}$ samples produced. These techniques included $\mathrm{X}$-ray diffraction using a Siemens $D 500$ x-ray diffractometer with the diffraction angles scanning from $2 \theta=20^{\circ}$ $80^{\circ}$, using a $\mathrm{Cu} \mathrm{K} \alpha$ radiation source. The crystallite size for each sample was calculated using the Scherrer equation $(D=0.9 \lambda / \beta \cos \theta)$ where $D=$ crystalline size, $\lambda=$ is the $x$-ray radiation wavelength $(0.154 \mathrm{~nm}), \beta=$ is the full line width at half-maximum height of the main intensity peak and $\theta=$ Bragg's angle. Raman spectroscopy carried out using a Horiba Jobin Yvon LabRAM HR system was used to confirm the crystalline phase present in the desired samples. Samples were analysed using the 50x objective lens at varying filter percentages between 1-100\% which varied according to the intensity recorded for each samples. A 300 grating and a scan range of $0-1200 \mathrm{~cm}^{-1}$ was used in all experiments with each run having an exposure time of 3 seconds. The Spectrum GXFTIR spectrophotometer was used to confirm the formation of $\mathrm{TiO}_{2}$ and its bonding capabilities with the dopants present, measured over a range of $400-4000 \mathrm{~cm}^{-1}$ with an accumulation of 8 scans. In order to study the optical properties, the diffuse absorbance 
spectra of samples were measured using a Perkin Elmer Lambda 900 UV-Vis absorption spectrophotometer between 300 and $600 \mathrm{~nm}$.

\subsection{Photocatalytic Studies}

Photocatalysis studies were carried out using rhodamine 6G under various light sources including; simulated solar, UV light and visible light irradiation. These studies were carried out by varying parameters to determine the optimum amount of sample and dye for degradation analysis. These parameters were time, concentration of sample, concentration of pollutant and the light source used. The rhodamine dye was irradiated by all light sources and was seen to have no degradation in the absence of a catalyst.

Photocatalysis studies involving rhodamine $6 \mathrm{G}$ were carried out using solar light provided by a Q-Sun solar simulator at $340 \mathrm{~nm}$ with a power outage of $0.28 \mathrm{~W} / \mathrm{m}^{2} .25 \mathrm{mg}$ of each sample was added to $50 \mathrm{mls}$ of $8.62 \times 10^{-6} \mathrm{M}$ of rhodamine $6 \mathrm{G}$. Aliquots were taken at 10 minute intervals for a period of 60 minutes and then centrifuged to remove all solids remaining in solution. These samples were then analysed using the UV-Vis spectrometer to measure their degradation properties.

\section{Results and Discussion}

\subsection{X-Ray Diffraction Spectroscopy}

The crystal structure of the undoped $\mathrm{TiO}_{2}$ and $\mathrm{N}, \mathrm{F}$ doped $\mathrm{TiO}_{2}$ was determined by X-ray diffraction with $\mathrm{Cu} \mathrm{K} \alpha$ radiation. Figure 1 shows the X-ray diffraction pattern of the nondoped $\mathrm{TiO}_{2}$ sample, 1:2 $\mathrm{TiO}_{2}: \mathrm{NH}_{4} \mathrm{~F}$ and the 1:8 $\mathrm{TiO}_{2}: \mathrm{NH}_{4} \mathrm{~F}$ sample which were all 
calcined at $200{ }^{\circ} \mathrm{C}$ and the formation of an alternative phase is shown. From these results, the titanium dioxide prepared without ammonium fluoride doping is seen to be forming crystalline anatase $\mathrm{TiO}_{2}$ at a calcination temperature of $200{ }^{\circ} \mathrm{C}$ with identification peaks seen at $25^{\circ}, 38^{\circ}, 48^{\circ}$ and $54^{\circ}$. When $\mathrm{NH}_{4} \mathrm{~F}$ is added, prominent peaks located at $23^{\circ}$ and $27^{\circ}$ appeared. This intermediate compound is seen alongside the anatase phase only when the titania precursor is modified with ammonium fluoride. The intermediate has been identified as the ammonium oxofluorotitanate $\left(\mathrm{NH}_{4} \mathrm{TiOF}_{3}\right)$ [33] and is formed upon heat treatment.

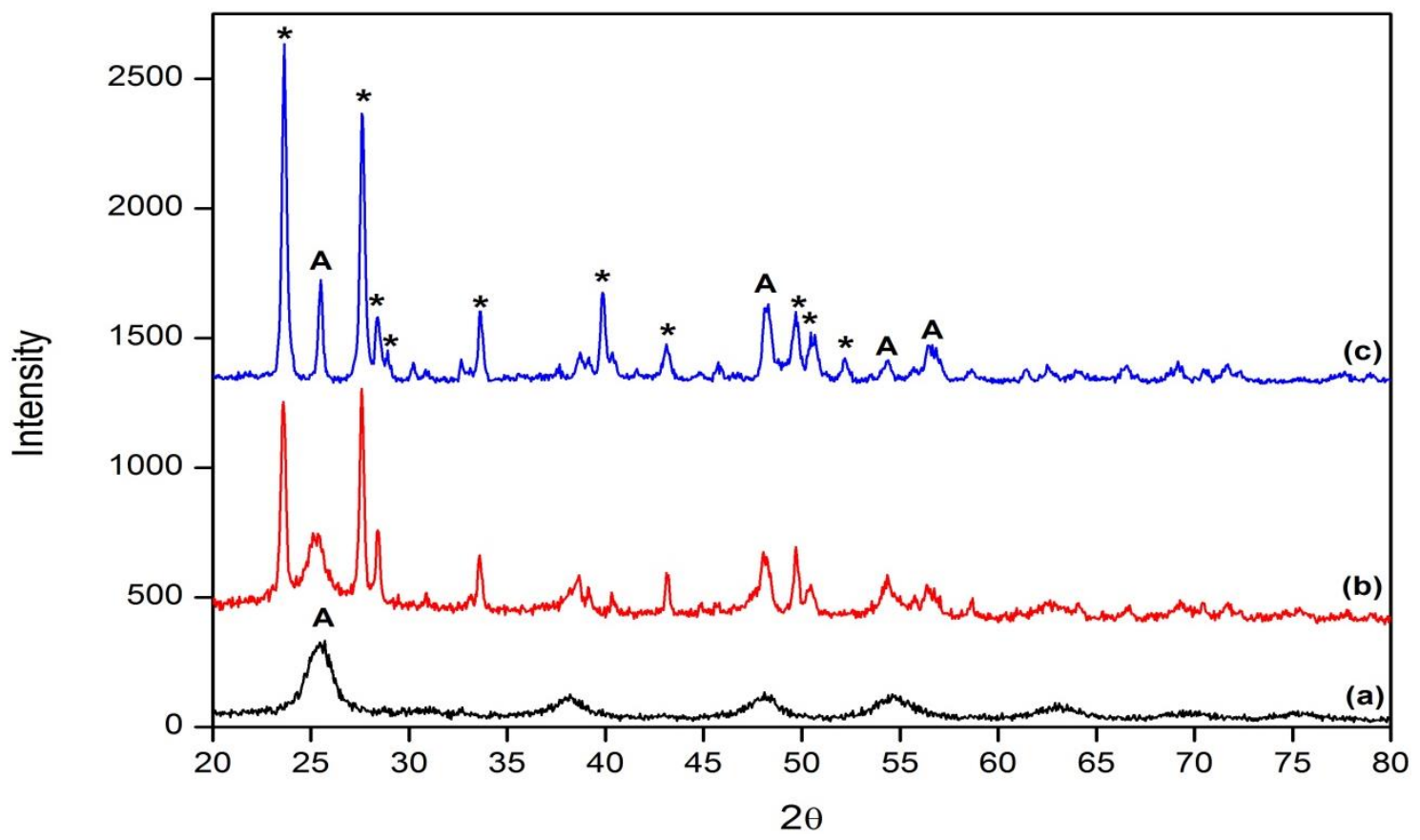

Figure 1. Comparison XRDs of undoped $\mathrm{TiO}_{2}$ and $\mathrm{N}, \mathrm{F}$ co-doped $\mathrm{TiO}_{2}$ all calcined at 200 ${ }^{\circ} \mathrm{C}$. (a) Undoped $\mathrm{TiO}_{2}$, (b) 1:2 $\mathrm{TiO}_{2}: \mathrm{NH}_{4} \mathrm{~F}$ and (c) 1:8 $\mathrm{TiO}_{2}: \mathrm{NH}_{4} \mathrm{~F}$.

* indicates the presence of the ammonium oxofluorotitanate $\left(\mathrm{NH}_{4} \mathrm{TiOF}_{3}\right)$ and $\mathrm{A}=$ Anatase 
The crystallite size for each sample was calculated over the temperature range of 400$1200{ }^{\circ} \mathrm{C}$. For the undoped and samples doped at a ratio of $1: 1$ and $1: 2 \mathrm{TiO}_{2}: \mathrm{NH}_{4} \mathrm{~F}$, the particle sizes grew by a factor of $5,(6.4$ to $38.6 \mathrm{~nm}),(3.6$ to $39.3 \mathrm{~nm})$ and (7.9 to 40.9 $\mathrm{nm})$ respectively. At the higher doped samples (1:4 and 1:8) the particles size growth rate was significantly reduced, with a growth of a factor of 2 occurring, 23.4 to 49.4 and 28.6 to $51 \mathrm{~nm}$ respectively, (Table 1). Even though the higher doped samples have a larger initial particle size, the formation of the intermediate greatly reduces the particle size growth of the samples whilst also retarding the anatase to rutile transition up to a higher temperature range.

The transition between the anatase and rutile phases at $900{ }^{\circ} \mathrm{C}$ (Figure 2) and $1200{ }^{\circ} \mathrm{C}$ (Figure 3) are shown. The key to the high temperature phase stability is the presence of ammonium fluoride in a 1:8 ratio. At lower ratios (1:1, 1:2 and 1:4) and in the absence of ammonium fluoride the anatase to rutile transition happens at a lower temperature. As the amount of dopant added to the titania is increased, the temperature to which the anatase is retained is also increased. The anatase to rutile percentage is measured using the Spurr equation. In the undoped sample, no anatase is present when the sample was calcined at $900{ }^{\circ} \mathrm{C}$ and above. At the lower doped samples, $1: 1 \mathrm{TiO}_{2}: \mathrm{NH}_{4} \mathrm{~F}$ and 1:2 $\mathrm{TiO}_{2}: \mathrm{NH}_{4} \mathrm{~F}$, the amount of rutile decreases but is still present at a much higher ratio than anatase for example $13.6 \% \mathrm{~A}$ and $86.4 \% \mathrm{R}$ and $12.3 \% \mathrm{~A}$ and $87.7 \% \mathrm{R}$ respectively. As the amount of the $\mathrm{NH}_{4} \mathrm{~F}$ dopant is increased, the percentage of anatase remaining at higher temperatures is high. For the $1: 4 \mathrm{TiO}_{2}: \mathrm{NH}_{4} \mathrm{~F}$ samples the ratio is $49.7 \% \mathrm{~A}$ and $50.3 \% \mathrm{R}$. For the 1:8 $\mathrm{TiO}_{2}: \mathrm{NH}_{4} \mathrm{~F}$ sample, there is very little amount of rutile present in the sample. The only sample in which rutile can be seen is that which has been calcined at $1200{ }^{\circ} \mathrm{C}$. 
In this sample $57.1 \% \mathrm{~A}$ is present compared to the $42.9 \% \mathrm{R}$. This can also be due to the formation of the oxofluorotitanates at the higher doped samples seen in Figure 1. The titanates could be the cause of the delayed anatase to rutile transformation and this therefore maintains the anatase phase at a temperature as high as $1200{ }^{\circ} \mathrm{C}$. By keeping the anatase phase at this point, the sample retains its photocatalytic ability at these high temperatures.

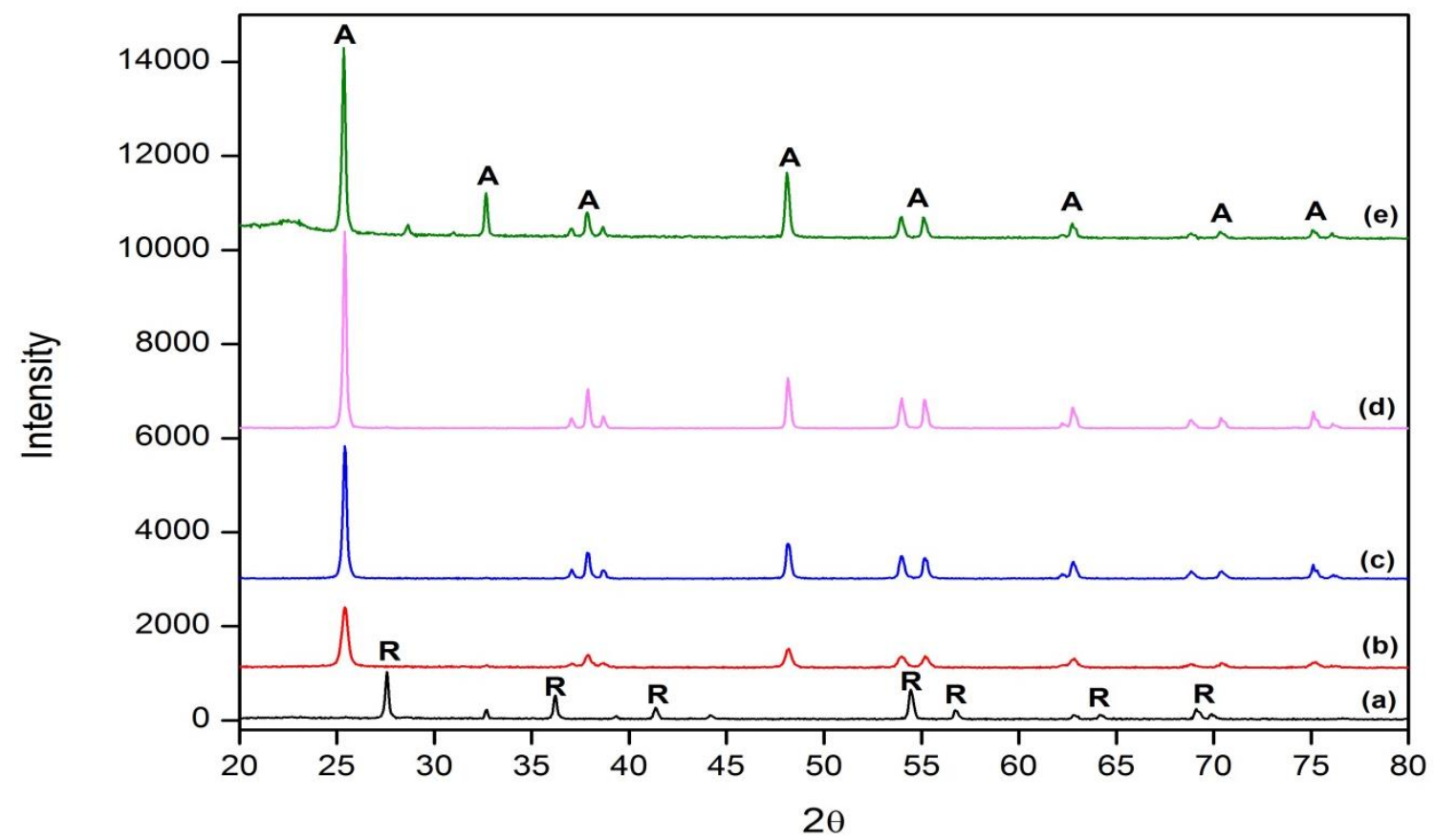

Figure 2. Comparison $\mathrm{XRDs}$ of undoped $\mathrm{TiO}_{2}$ and $\mathrm{N}, \mathrm{F}$ co-doped $\mathrm{TiO}_{2}$ at various ratios of dopants calcined at $900{ }^{\circ} \mathrm{C}$. (a) Undoped $\mathrm{TiO}_{2}$, (b) 1:1 $\mathrm{TiO}_{2}: \mathrm{NH}_{4} \mathrm{~F}$, (c) 1:2 $\mathrm{TiO}_{2}: \mathrm{NH}_{4} \mathrm{~F}$, (d) 1:4 $\mathrm{TiO}_{2}: \mathrm{NH}_{4} \mathrm{~F}$ and (e) 1:8 $\mathrm{TiO}_{2}: \mathrm{NH}_{4} \mathrm{~F}$.

$* \mathrm{~A}=$ Anatase and $* \mathrm{R}=$ Rutile 


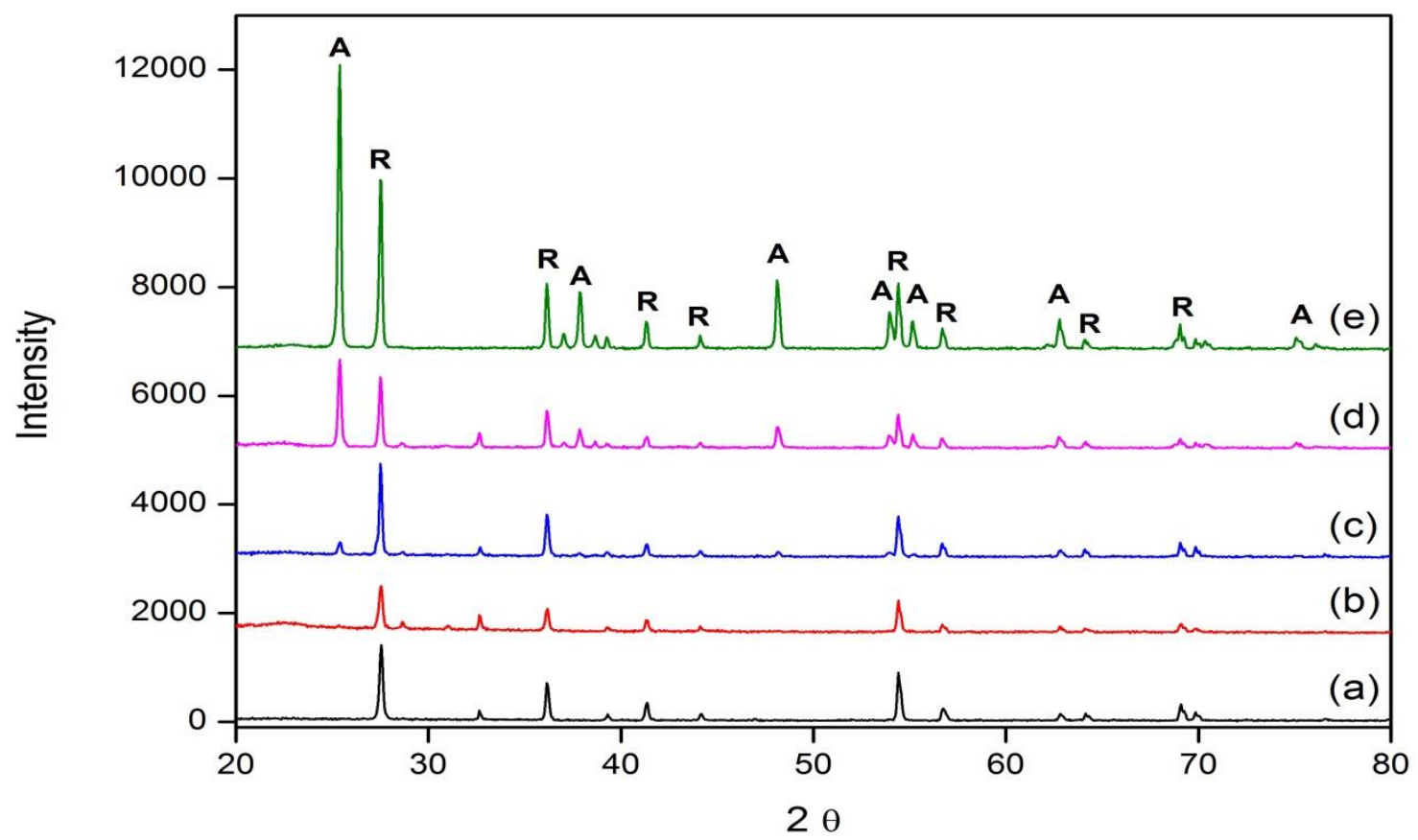

Figure 3. Comparison XRDs of non-doped $\mathrm{TiO}_{2}$ and $\mathrm{N}, \mathrm{F}$ co-doped $\mathrm{TiO}_{2}$ at various ratios of dopants calcined at $1200{ }^{\circ} \mathrm{C}$. (a) Undoped $\mathrm{TiO}_{2}$, (b) 1:1 $\mathrm{TiO}_{2}: \mathrm{NH}_{4} \mathrm{~F}$, (c) 1:2 $\mathrm{TiO}_{2}: \mathrm{NH}_{4} \mathrm{~F}$, (d) 1:4 $\mathrm{TiO}_{2}: \mathrm{NH}_{4} \mathrm{~F}$ and (e) $1: 8 \mathrm{TiO}_{2}: \mathrm{NH}_{4} \mathrm{~F}$.

* A = Anatase and $* \mathrm{R}=$ Rutile 
Table 1. Particle size of non-doped and $\mathrm{NH}_{4} \mathrm{~F}$ doped $\mathrm{TiO}_{2}$ samples.

\begin{tabular}{|l|l|l|l|l|}
\hline & & \multicolumn{3}{|l|}{ Particle size (nm) - Anatase } \\
\hline & Temp ( $\left.{ }^{\circ} \mathrm{C}\right)$ & 200 & $\mathbf{4 0 0}$ & $\mathbf{1 2 0 0}$ \\
\hline & & & & \\
\hline 1 & $\mathrm{TiO}_{2}$ & 5.7 & 8.4 & $46.4(\mathrm{R})$ \\
\hline 2 & $1: 1 \mathrm{TiO}_{2}: \mathrm{NH}_{4} \mathrm{~F}$ & 4.9 & 11.3 & $39.3(\mathrm{R})$ \\
\hline 3 & $1: 2 \mathrm{TiO}_{2}: \mathrm{NH}_{4} \mathrm{~F}$ & 8.4 & 21.7 & 40.5 \\
\hline 4 & $1: 4 \mathrm{TiO}_{2}: \mathrm{NH}_{4} \mathrm{~F}$ & 20.2 & 37.3 & 49.4 \\
\hline 5 & $1: 8 \mathrm{TiO}_{2}: \mathrm{NH}_{4} \mathrm{~F}$ & 33.6 & 36.5 & 51.0 \\
\hline
\end{tabular}

\subsection{Raman Spectroscopy}

Raman spectroscopy was employed as an additional tool to confirm the presence of crystalline material in doped and undoped $\mathrm{TiO}_{2}$. The anatase phase of $\mathrm{TiO}_{2}$ consists of six $\left(144,197,399,513\right.$, and $\left.639 \mathrm{~cm}^{-1}\right)$ Raman active modes whereas the rutile form consists of five $\left(144,446,612,827 \mathrm{~cm}^{-1}\right)$ [34]. Figure 4 shows the anatase phase being quite prominent in the $1: 8 \mathrm{NH}_{4} \mathrm{~F}$ doped $\mathrm{TiO}_{2}$ at $1200{ }^{\circ} \mathrm{C}$. A comparison between this sample and an undoped $\mathrm{TiO}_{2}$ at the same temperature allows us to clearly see the phase differences present as the rutile form was detected. 


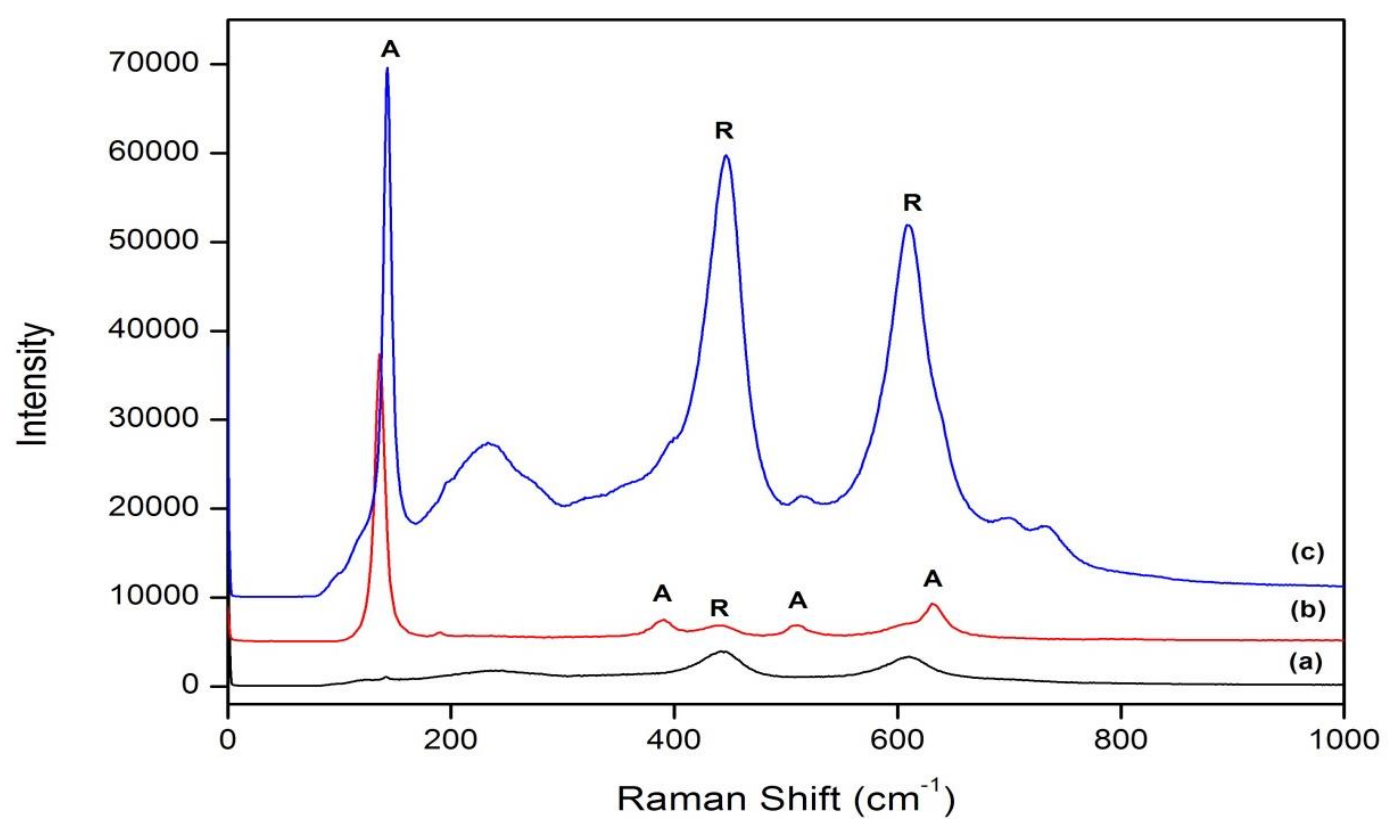

Figure 4. Raman spectra of (a) undoped $\mathrm{TiO}_{2}$, (b) 1:8 $\mathrm{TiO}_{2}: \mathrm{NH}_{4} \mathrm{~F}$ and (c) 1:2 $\mathrm{TiO}_{2}: \mathrm{NH}_{4} \mathrm{~F}$, $400 \mathrm{~W} 20$ minutes calcined at $1200{ }^{\circ} \mathrm{C}$

$* \mathrm{~A}=$ Anatase and $* \mathrm{R}=$ Rutile

\subsection{Fourier Transform Infrared Spectroscopy}

The FTIR spectra of the undoped and $\mathrm{NH}_{4} \mathrm{~F}$ doped $\mathrm{TiO}_{2}$ were recorded and analysed for the purpose of determining bonds formed during doping (Figure 5). The peaks seen at 3550-3000 $\mathrm{cm}^{-1}$ and $1600 \mathrm{~cm}^{-1}$ in both spectra indicate hydroxyl group stretching vibrations. The strong peak at $1416 \mathrm{~cm}^{-1}$ indicates $\mathrm{N}-\mathrm{H}$ bonds present due to the deformation mode of ammonium ions. A wide band formed around $500 \mathrm{~cm}^{-1}$ in the undoped sample can be attributed to the Ti-O-Ti bonds formed in the preparation of the $\mathrm{TiO}_{2}$. In the doped samples, the broad peak between $500 \mathrm{~cm}^{-1}$ and $990 \mathrm{~cm}^{-1}$ may possibly be due to the combination of Ti-O and Ti-F bonds or a lattice mode of these...? [35]. 


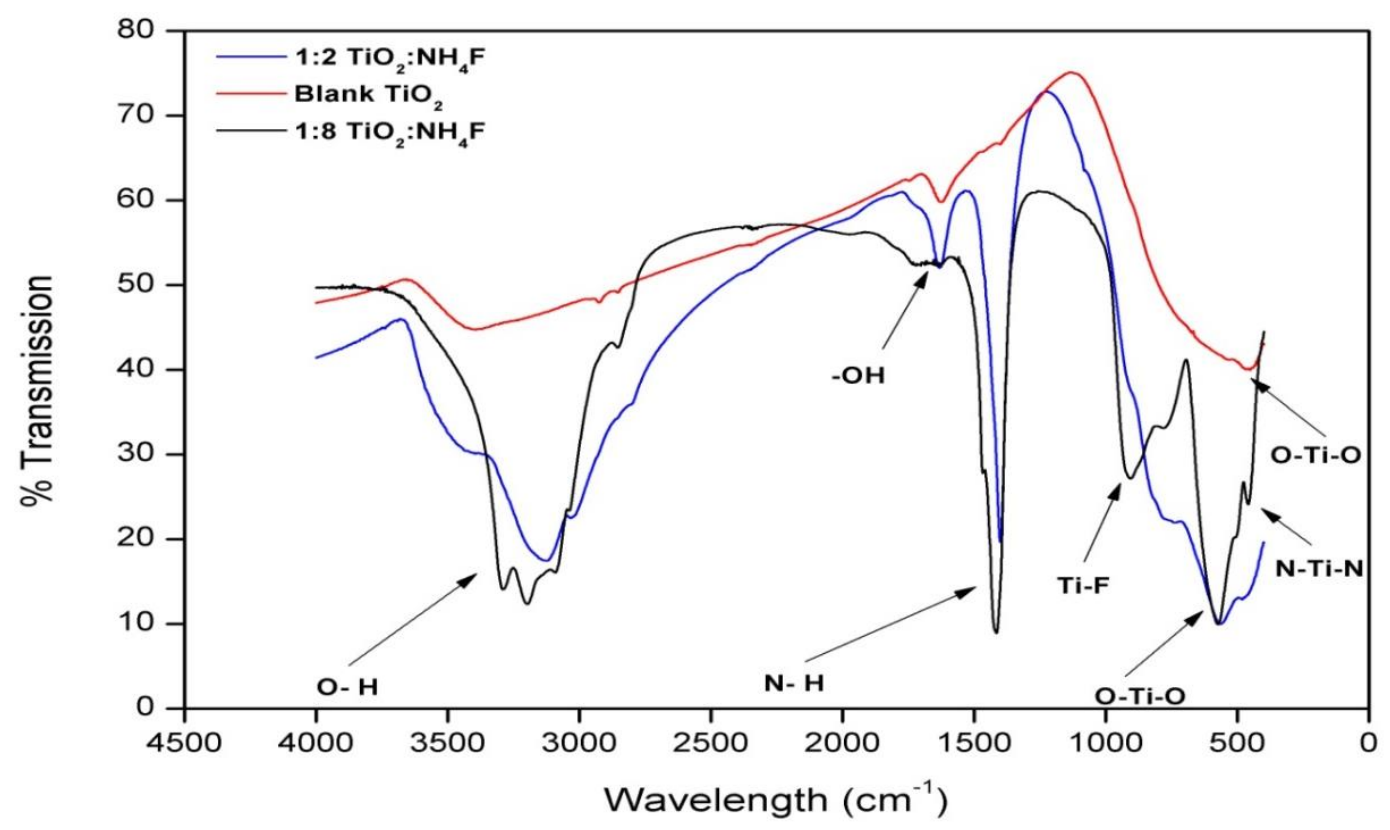

Figure 5. FT-IR spectra of $\mathrm{TiO}_{2}$ and 1:8 $\mathrm{TiO}_{2}: \mathrm{NH}_{4} \mathrm{~F}$ calcined at $200{ }^{\circ} \mathrm{C}$ showing the addition of $\mathrm{N}$ and $\mathrm{F}$ related bonds within the doped $\mathrm{TiO}_{2}$ sample.

\subsection{Photocatalysis Studies}

There are many factors that affect the photocatalytic properties of $\mathrm{TiO}_{2}$. These include the phase composition, crystallinity, particle size, surface area, retention of added dopant in the prepared material, absorption properties of the dye onto the surface of the $\mathrm{TiO}_{2}$ used, rate of electron-hole recombination and the number of electrons created [22,36]. From the photocatalysis results for samples calcined at $1200{ }^{\circ} \mathrm{C}$, the rates calculated for all samples using visible light only were negligible, showing that the undoped $\mathrm{TiO}_{2}, 1: 8 \mathrm{NH}_{4} \mathrm{~F}$ : $\mathrm{TiO}_{2}$ and Degussa were all inactive. The 1:8 $\mathrm{TiO}_{2}: \mathrm{NH}_{4} \mathrm{~F}, \mathrm{MW}, 1200{ }^{\circ} \mathrm{C}$ sample has a rate of reaction calculated as being $0.0068 \mathrm{~min}^{-1}$ when UV light is used. These degradation rates 
are very low and very little visual diminution is observed experimentally by UV-Vis spectroscopy. In comparison, the undoped $\mathrm{TiO}_{2}$ at $1200{ }^{\circ} \mathrm{C}$ had a measurable rate of $0.0091 \mathrm{~min}^{-1}$, making this 1.3 times faster than the doped sample. After comparisons between undoped $\mathrm{TiO}_{2}$ and samples prepared a microwave method, which were all calcined at $1200{ }^{\circ} \mathrm{C}$, the standard Degussa was analysed to relate the rates of the prepared samples to a commercial standard. The dye degradation by the standard at a comparable temperature of $1200{ }^{\circ} \mathrm{C}$ shows a drastically reduced to rate of $0.0027 \mathrm{~min}^{-1}$, making it 2.5 times less effective than the 1:8 $\mathrm{TiO}_{2}: \mathrm{NH}_{4} \mathrm{~F}, 1200{ }^{\circ} \mathrm{C}$ sample. Under solar light irradiation, the undoped $\mathrm{TiO}_{2}$ and Degussa standard were seen to be inactive, with calculated rates being $0.0015 \mathrm{~min}^{-1}$ and $0.0021 \mathrm{~min}^{-1}$ respectively. When the $1: 8 \mathrm{NH}_{4} \mathrm{~F}$ : $\mathrm{TiO}_{2}$ sample was analysed, a rate of reaction of $0.0031 \mathrm{~min}^{-1}$ was measured, showing this to be more active than the undoped and the standard, even though the values are still quite low.

\section{Discussion}

With the aim of producing a high temperature stable anatase $\mathrm{TiO}_{2}$ photocatalyst, a combination of microwave pre-treatment and co-doping with non-metals was studied. With the microwave providing an efficient production method, nitrogen suggested to provide the generation of discrete energy levels above the valence band (midgap state) [37] and fluorine proposed to not only retard the anatase to rutile transition, but to increase concentration of ${ }^{\circ} \mathrm{OH}$ radicals in solution, a highly effective and stable anatase photocatalyst is anticipated. The use of nitrogen and fluorine as dopants has been studied extensively for their effectiveness in altering the properties of $\mathrm{TiO}_{2}$. Nitrogen can be used as a dopant in the alteration of the band-gap of $\mathrm{TiO}_{2}$ 
introducing filled $\mathrm{N} 2 p$ states above the $\mathrm{TiO}_{2}$ valence band $[38,39]$. The $\mathrm{N}-2 p$ orbitals provide a step-up for the electrons coming from the valence band and make the jump to the conduction band much smaller. A notable factor in nitrogen doping is that different forms of doping can occur; interstitial or substitutional, and the form of doping attained depends heavily upon the preparation method used $[1,39]$. Substitutional nitrogen, where nitrogen successfully replaced an oxygen atom in the titania lattice, tends to have a positive effect on band gap reduction by mixing with valence band states [1]. Interstitial nitrogen doping occurs when additional electronic states are found to form above the upper edge of the valence band. In literature, the form of nitrogen doping responsible for inducing visible light activity is still being debated. Di Valentin et al. [41] have previously stated that both substitutional and interstitial doping provide the formation of localised occupied states in the band gap leading to visible light activity. Extensive study of using nitrogen as a dopant of $\mathrm{TiO}_{2}$ shows that effective nitrogen doping occurs in the form of interstitial doping rather than substitutional [42-46]. Fluorine doping is also effective in causing modifications of the electronic structure of $\mathrm{TiO}_{2}$ by the formation of surface oxygen vacancies due to charge compensation between $\mathrm{F}^{-}$and $\mathrm{Ti}^{4+}$ but without creating a substantial variation in the optical absorption of $\mathrm{TiO}_{2}$ [47]. F-doping is understood to not only retard the anatase to rutile transition, but causes an increase in the concentration of ${ }^{\circ} \mathrm{OH}$ radicals in solution, improving the photo-degradation rate of organic compounds [29]. Also, the $\mathrm{F}^{-}$ions provided lead to substitution of the oxygen in the solid lattice which gives rise to electronic effects which favour $\mathrm{N}$ photoactive species incorporation in the solid [48].

A proposed scheme for the formation of the oxofluorotitanates and the retention of the anatase phase is shown in Figure 6. Normally, the anatase to rutile transition is a gradual 
occurrence in respect to both temperature and time with the anatase phase converting to the rutile phase at temperatures of $600-700{ }^{\circ} \mathrm{C}$ under typical synthesis conditions. In this study, undoped anatase $\mathrm{TiO}_{2}$ is formed upon calcination temperatures of $200{ }^{\circ} \mathrm{C}$, with a highly crystalline form appearing after $400{ }^{\circ} \mathrm{C}$. The anatase phase is then measured for each sample up to and including $800{ }^{\circ} \mathrm{C}(95 \% \mathrm{~A})$. The anatase phase is only completely converted to $100 \%$ rutile by $900{ }^{\circ} \mathrm{C}$. In comparison, when a typical sol-gel preparation method was used it was seen that the rutile phase was the majority phase present at $800 \mathrm{C}$ (15\% A and $85 \% \mathrm{R})$. This highlights that through the use of the microwave pre-treatment, the anatase to rutile transformation temperature has been successfully extended. When ammonium fluoride is added during the preparation stage (section 2.2), oxofluorotitanate, $\mathrm{NH}_{4} \mathrm{TiOF}_{3}$, was seen to form upon calcination temperatures of $200{ }^{\circ} \mathrm{C}$ alongside the anatase phase. After the formation of oxofluorotitanate, anatase was seen to be retained much longer than undoped $\mathrm{TiO}_{2} .100 \%$ anatase was seen for all samples except at 1200 ${ }^{\circ} \mathrm{C}$ where an anatase and rutile mixture was detected. The titanates were then deemed to be responsible for the retention of the anatase phase at high temperatures and therefore the postponement of the rutile formation.

The effect that the ammonium fluoride has on the crystal growth of the titania nanoparticles is one of the factors that affects the anatase to rutile transition. Even though the higher doped samples have a larger initial particle size (Table 1), the inclusion of the intermediate greatly reduces the particle size growth of the samples as well as retarding the anatase to rutile transition up to a higher temperature range. 


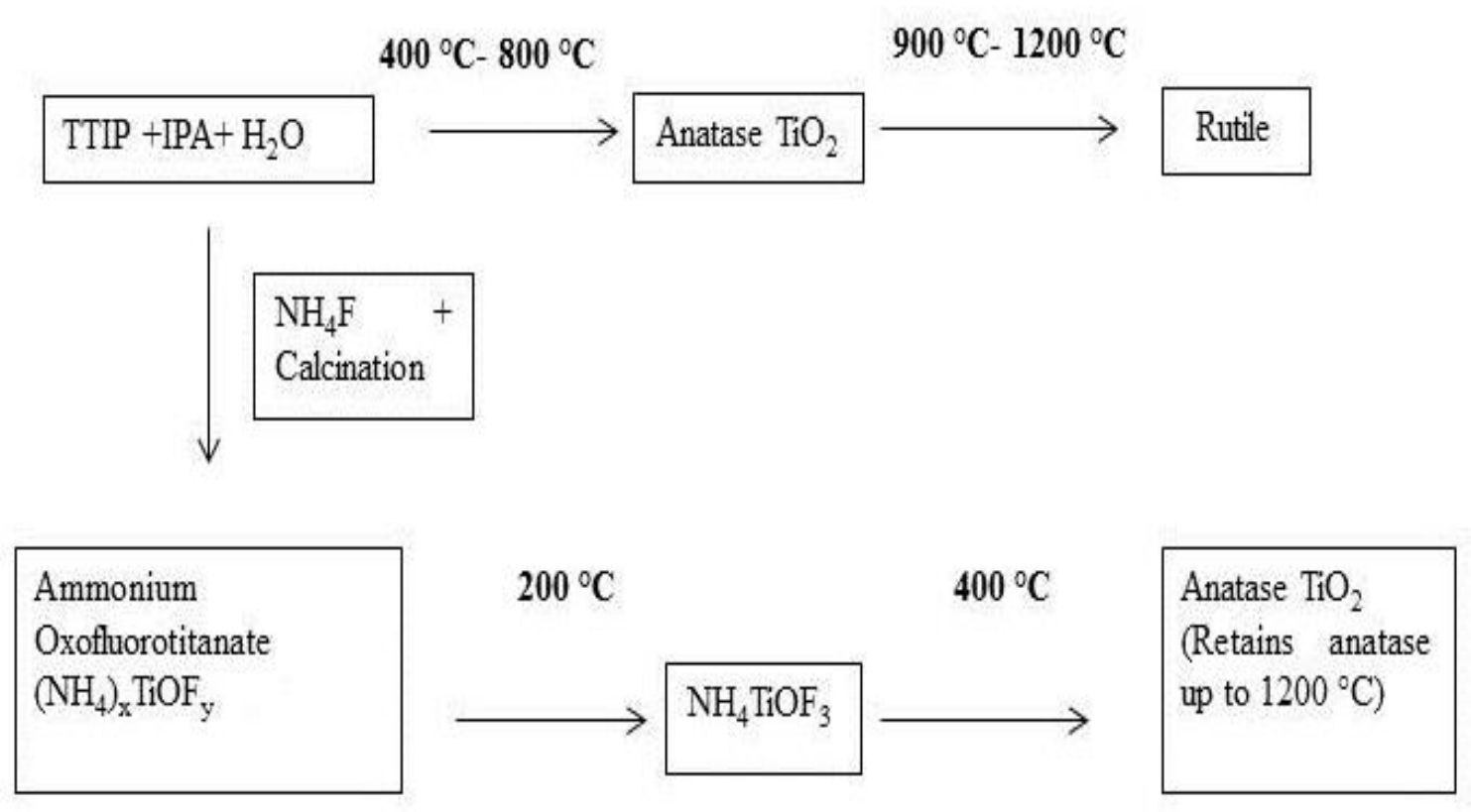

Figure 6. Proposed scheme for the formation of high temperature stable anatase.

As mentioned earlier, the photocatalytic efficiency of a material is based on several factors. During this study, it was deemed that the undoped and 1:8 $\mathrm{TiO}_{2}: \mathrm{NH}_{4} \mathrm{~F}$ samples at $1200{ }^{\circ} \mathrm{C}$ have similar particle sizes (Table 1) and high levels of crystallinity, and therefore are not believed to be deciding factors in the resulting rates. The photocatalytic rates were affected mainly due to differing phase compositions within the samples. Anatase is known to have a higher number of hydroxyl radicals on its surface, leading it to exhibit an increased reactivity on its surface as opposed to the rutile phase which is seen to encourage the dissociation of organic molecules from its surface. The presence of $100 \%$ rutile in the undoped sample also leads us to believe that an increased electron-hole recombination rate is responsible for its lower reactivity. Diffuse absorbance spectroscopy studies show no shift in the band gap towards the visible light region for the doped samples and showed a typical band gap of $3.18 \mathrm{eV}$ for the sample 1:8 $\mathrm{TiO}_{2}: \mathrm{NH}_{4} \mathrm{~F}, 1200$ 
${ }^{\circ} \mathrm{C}$ and $2.96 \mathrm{eV}$ (rutile) for the undoped $\mathrm{TiO}_{2}$ at this temperature. This is not surprising because at such high temperatures the dopants are expected to be burned off during calcination. It is a combined effect of the oxofluorotitanates formed at low temperatures delaying the anatase to rutile transition and greater phase stability at such high temperatures in the microwave samples that allow it to be a better photocatalyst when compared to the (traditional) sol-gel material.

\section{Conclusions}

Microwave treatment is an improved way of producing crystalline $\mathrm{TiO}_{2}$ and is preferable due to its cost effectiveness. Various doped samples of titanium isopropoxide and ammonium fluoride $\left(\mathrm{NH}_{4} \mathrm{~F}\right)$ were used to prepare $\mathrm{N}, \mathrm{F}-\mathrm{TiO}_{2}$ using a microwave method and calcined at temperatures of $100{ }^{\circ} \mathrm{C}$ intervals between $200-1200{ }^{\circ} \mathrm{C}$. Characterisation techniques including XRD, Raman spectroscopy, FTIR, diffuse absorbance and photocatalysis were used to characterise the produced materials and their ability to degrade different pollutants and/or dyes.

During the study of doping of titanium dioxide with ammonium fluoride, a method for the formation of high temperature stable anatase was found. $57.1 \%$ Anatase at $1200{ }^{\circ} \mathrm{C}$ was prepared which is considerably higher than previously presented reports of $40 \%$ anatase at $1150{ }^{\circ} \mathrm{C}$ [33]. With $\mathrm{XRD}$ analysis, the main attributing factor to this anatase retention was seen to be the formation of the oxofluorotitanate material at low temperatures (200 $\left.{ }^{\circ} \mathrm{C}\right)$. This titanate species greatly affected the particle sizes measured, by forming a higher initial particle size in comparison to the non-doped and lower doped samples but a reduced grain growth rate with increasing temperatures. In our study of microwave 
treatment as a pre-step in the preparation of photocatalytic $\mathrm{TiO}_{2}$, it is seen to produce more effective photocatalysts when compared to other methods such as sol-gel processing. It can be proved to increase the crystallinity and improve the retention of dopants in the $\mathrm{TiO}_{2}$ lattice to increase reactivity of the samples.

The retention of a stable anatase at high temperatures $\left(>1000^{\circ} \mathrm{C}\right)$ opens up the use of this material into various industries such as the production of building materials such as ceramic tiles, roof tiles and glass for disinfection purposes.

\section{Acknowledgements}

The authors wish to acknowledge financial support from the U.S. Ireland R\&D Partnership Initiative, Science Foundation Ireland (SFI-grant number 10/US/I1822(T)).

\section{References}

[1] S.U.M. Khan, M. Al-Shahry, W.B. Ingler, Science 297 (2002) 2243.

[2] Y. Inoue, Energy Environ. Sci. 2 (2009) 364.

[3] L. Zhang, H.H. Mohamed, R. Dillert, D. Bahnemann, J. Photochem. Photobiol. C Photochem. Rev. 13 (2012) 263.

[4] R. Fateh, A.A. Ismail, R. Dillert, D.W. Bahnemann, J. Phys. Chem. C 115 (2011) 10405.

[5] A. Mills, J. Hepburn, D. Hazafy, C. O’Rourke, J. Krysa, M. Baudys, M. Zlamal, H. Bartkova, C.E. Hill, K.R. Winn, M.E. Simonsen, E.G. Søgaard, S.C. Pillai, N.S. Leyland, R. Fagan, F. Neumann, C. Lampe, T. Graumann, J. Photochem. Photobiol. A Chem. 272 (2013) 18. 
Fagan et al, Applied Surface Science 371, 2016, 447-452

[6] S. Banerjee, D.D. Dionysiou, S.C. Pillai, Appl. Catal. B Environ. 176-177 (2015) 396.

[7] J.W. MacFarlane, H.F. Jenkinson, T.B. Scott, Appl. Catal. B Environ. 106 (2011) 181.

[8] K. Hashimoto, H. Irie, A. Fujishima, Jpn. J. Appl. Phys. 44 (2005) 8269.

[9] T. Tatsuma, W. Kubo, A. Fujishima, Langmuir 18 (2002) 9632.

[10] Z. Zsilák, E. Szabó-Bárdos, O. Fónagy, O. Horváth, K. Horváth, P. Hajós, Catal. Today 230 (2014) 55.

[11] V. Vamathevan, R. Amal, D. Beydoun, G. Low, S. McEvoy, J. Photochem. Photobiol. A Chem. 148 (2002) 233.

[12] Y. Ohko, S. Saitoh, T. Tatsuma, A. Fujishima, J. Electrochem. Soc. 148 (2001) B24.

[13] T. Tatsuma, S. Saitoh, Y. Ohko, A. Fujishima, Chem. Mater. 13 (2001) 2838.

[14] W. Su, J. Zhang, Z. Feng, T. Chen, P. Ying, C. Li, J. Phys. Chem. C 112 (2008) 7710.

[15] U. Diebold, Surf. Sci. Rep. 48 (2003) 53.

[16] J. Ryu, W. Choi, Environ. Sci. Technol. 42 (2008) 294.

[17] W. Choi, A. Termin, M.R. Hoffmann, J. Phys. Chem. 98 (1994) 13669.

[18] P. Wen, C. Cai, H. Zhong, L. Hao, X. Xu, J. Mater. Sci. 50 (2015) 5944.

[19] M. Pelaez, N.T. Nolan, S.C. Pillai, M.K. Seery, P. Falaras, A.G. Kontos, P.S.M. Dunlop, J.W.J. Hamilton, J.A. Byrne, K. O’Shea, M.H. Entezari, D.D. Dionysiou, Appl. Catal. B Environ. 125 (2012) 331.

[20] S. Sakthivel, H. Kisch, Angew. Chemie - Int. Ed. 42 (2003) 4908. 
Fagan et al, Applied Surface Science 371, 2016, 447-452

[21] M. Kang, Mater. Lett. 59 (2005) 3122.

[22] P. Periyat, D.E. McCormack, J. Colreavy, S.C. Pillai, S.J. Hinder, J. Phys. Chem. 112 (2008) 7644.

[23] P. Periyat, D.E. McCormack, S.J. Hinder, S.C. Pillai, J. Phys. Chem. C 113 (2009) 3246.

[24] S.C. Padmanabhan, S. Pillai, J. Colreavy, S. Balakrishman, D.E. McCormack, T.S. Perova, Y. Gun'ko, S.J. Hinder, J.M. Kelly, Chem. Mater. 19 (2007) 4474.

[25] Y. Lv, L. Yu, H. Huang, H. Liu, Y. Feng, Appl. Surf. Sci. 255 (2009) 9548.

[26] K. Lv, Q. Xiang, J. Yu, Appl. Catal. B Environ. 104 (2011) 275.

[27] P.K.J. Robertson, J.M.C. Robertson, D.W. Bahnemann, J. Hazard. Mater. 211-212 (2012) 161.

[28] G.J. Wilson, G.D. Will, R.L. Frost, S.A. Montgomery, J. Mater. Chem. 12 (2002) 1787.

[29] Y. Wu, M. Xing, B. Tian, J. Zhang, F. Chen, Chem. Eng. J. 162 (2010) 710.

[30] X. Li, H. Zhang, X. Zheng, Z. Yin, L. Wei, J. Environ. Sci. 23 (2011) 1919.

[31] D.G. Huang, S.J. Liao, J.M. Liu, Z. Dang, L. Petrik, J. Photochem. Photobiol. A Chem. 184 (2006) 282.

[32] Y. Xie, Y. Li, X. Zhao, J. Mol. Catal. A Chem. 277 (2007) 119.

[33] M. Hojamberdiev, G. Zhu, P. Sujaridworakun, S. Jinawath, P. Liu, J.P. Zhou, Powder Technol. 218 (2012) 140.

[34] S.C. Pillai, P. Periyat, R. George, D.E. McCormack, M.K. Seery, H. Hayden, J. Colreavy, D. Corr, S.J. Hinder, (2007) 1605.

[35] P. Cheng, J. Qiu, M. Gu, Y. Jin, W. Shangguan, Mater. Lett. 58 (2004) 3751. 
Fagan et al, Applied Surface Science 371, 2016, 447-452

[36] S.Y. Choi, M. Mamak, N. Coombs, N. Chopra, G.A. Ozin, Adv. Funct. Mater. 14 (2004) 335 .

[37] C. Di Valentin, G. Pacchioni, A. Selloni, S. Livraghi, E. Giamello, J. Phys. Chem. B 109 (2005) 11414.

[38] H. Irie, Y. Watanabe, K. Hashimoto, J. Phys. Chem. B 107 (2003) 5483.

[39] R. Nakamura, T. Tanaka, Y. Nakato, J. Phys. Chem. B 108 (2004) 10617.

[40] R.G. Palgrave, D.J. Payne, R.G. Egdell, J. Mater. Chem. 19 (2009) 8418.

[41] C. Di Valentin, E. Finazzi, G. Pacchioni, A. Selloni, S. Livraghi, M.C. Paganini, E. Giamello, Chem. Phys. 339 (2007) 44.

[42] S. Banerjee, S.C. Pillai, P. Falaras, K.E. O'Shea, J.A. Byrne, D.D. Dionysiou, J. Phys. Chem. Lett. 5 (2014) 2543.

[43] N.T. Nolan, D.W. Synnott, M.K. Seery, S.J. Hinder, A. Van Wassenhoven, S.C. Pillai, J. Hazard. Mater. 211-212 (2012) 88.

[44] F. Peng, L. Cai, H. Yu, H. Wang, J. Yang, J. Solid State Chem. 181 (2008) 130.

[45] Y. Yalçin, M. Kiliç, Z. Çinar, J. Adv. Oxid. Technol. 13 (2010) 281.

[46] J. Ananpattarachai, P. Kajitvichyanukul, S. Seraphin, J. Hazard. Mater. 168 (2009) 253.

[47] D. Li, H. Haneda, N.K. Labhsetwar, S. Hishita, N. Ohashi, Chem. Phys. Lett. 401 (2005) 579 .

[48] S. Livraghi, K. Elghniji, A.M. Czoska, M.C. Paganini, E. Giamello, M. Ksibi, J. Photochem. Photobiol. A Chem. 205 (2009) 93. 
Fagan et al, Applied Surface Science 371, 2016, 447-452

Cite this article as Fagan et al, Applied Surface Science 371, 2016, 447-452

http://www.sciencedirect.com/science/article/pii/S0169433216304238 